\title{
HALAL TOURISM: LESSONS FOR DESTINATION MANAGERS OF NON-MUSLIM MAJORITY COUNTRIES
}

\author{
Nik Ramli Nik Abdul Rashid* \\ Universiti Teknologi MARA, Malaysia \\ Chutima Wangbenmad \\ Hatyai University, Thailand \\ Kamarul Ariffin Mansor \\ Universiti Teknologi MARA, Malaysia
}

\begin{abstract}
Muslim tourists spending are expected to grow significantly and could represent more than $13 \%$ of global tourism expenditure by the year 2020. The growth of younger and educated Muslims with larger disposable income has also further increase their propensity to travel abroad. This study explores the influence of perceived destination attributes on Muslim tourist satisfaction and eventual destination loyalty. The population of the study were Muslim travellers intercepted at the Penang International Airport. A purposive sampling procedure was applied and data collection was through self administered questionnaire. A structural equation modelling approach (using SmartPLS 3.0 software) was employed for data analysis and testing of the research model. The results of the analysis were critically discussed and suggestions were proposed, for practical and empirical purpose.
\end{abstract}

Keywords: Destination attributes; Halal tourism; Tourist satisfaction; Destination loyalty.

\section{INTRODUCTION}

Muslims population is expected to grow more than twice as fast as the overall world population between 2015 and 2060 (Lipka and Hackett, 2017). The gross domestic product (GDP) per capita of Muslim-majority countries such as Qatar, United Arab Emirates and Saudi Arabia are all above some developed countries, including Japan (Tanada, 2017). The growth of the Muslim population has attracted stakeholders of international business, including in the tourism sector. The Dinar Standard (2018), a New York based marketing research and advisory firm has estimated that the global Muslim tourism market is worth $\$ 126.1$ billion in outbound expenditure. This is approximately $12.3 \%$ of the total global tourism expenditure in 2011 . The same report has also forecasted that the Muslim tourist spending is expected to grow further to $\$ 192$ billion by 2020 , representing $13.4 \%$ of the global tourism expenditure. Another study conducted by MasterCard and Crescent Rating (2015) revealed Muslim travel market was worth \$145 billion, with 108

*Corresponding author: Faculty of Business and Management, Universiti Teknologi MARA,08400 Merbok, Kedah, Malaysia. Email: nikramli@kedah.uitm.edu.my Tel: +604 4562000 
million Muslim travellers representing $10 \%$ of the entire travel economy and is forecasted to grow to 150 million visitors by 2020 (which is $11 \%$ of the market) with an estimated expenditure projected to grow to $\$ 200$ billion. This optimistic trend is also contributed by the growth of younger and educated Muslim with a larger disposable income which has an increased propensity to travel. With this ongoing trend, Muslim travel could continue to be one of the fastest growing travel sectors in the world. Even though the above accounts of the Muslim travel market are approached in general, there are in actual fact important diverse aspects of that market. These significant diverse aspects might be associated to demographics or psychographics background of the Muslim society. It would be reasonable to suggest that the diversity elements could be reflected by the purpose of the visit and choice of travel destinations. This study is an attempt to explore the factors that influence Muslim travel satisfaction when choosing a non-Muslim majority country as the destination choice. The perceptions Muslim travellers have regarding potential destination attributes are divided into two groups, religious-related (availability of halal food and prayer facilities) and non-religious-related (security-safety and social-cultural attractions). This study will compare and look into the level of importance attached to the dimensions of each destination attributes and their influence on tourist satisfaction, and eventual destination loyalty.

The research model for this study is shown in Figure 1 below.

Figure 1: The Research Model

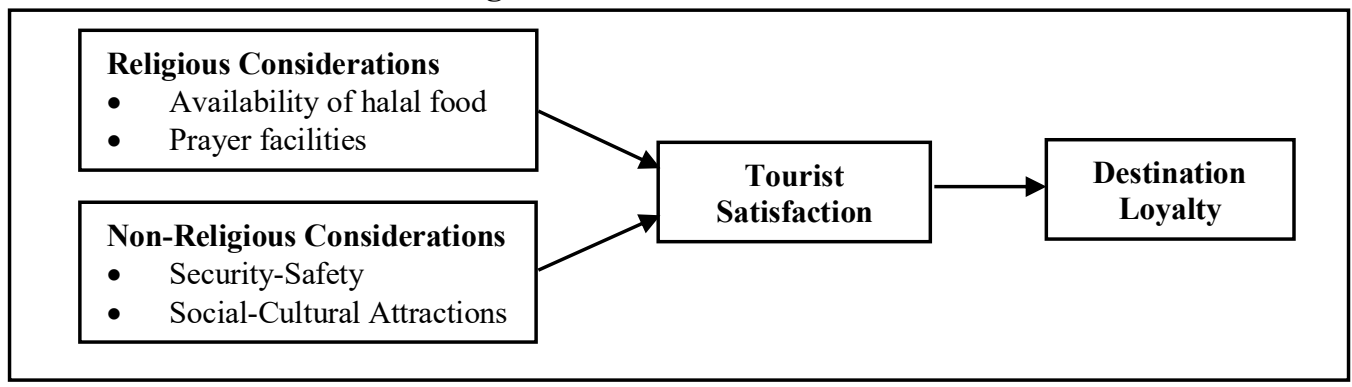

\section{LITERATURE REVIEW}

\subsection{Halal Tourism}

Halal tourism refers to the provision of a tourism product and service that adheres to the Islamic values, where the need of Muslim travelers to worship and the dietary requirement that conform to Islamic teachings is facilitated (Mohsin, Ramli, \&Alkhulayfi, 2016). The World Travel Market (2007) describes halal tourism as a type of tourism that is in conformity with the Islamic teaching regarding behaviorisms, conduct and diet. This study adopts a simpler definition by ZamaniFarahani\& Henderson (2010) that defined halal tourism as simply tourism by Muslims, who prefer to stay within their cultural and religious belief. Halal tourism must be differentiated from religious tourism, where the later form of tourism is motivated solely by religious or spiritual ritual and practices, such as pilgrimages, missionary travel, faith-base retreats etc. (El-Gohary, 2016). Table 1 provides several other definitions of halal tourism. 
From the tourism operators and stakeholders' perspectives, response to halal tourism could be observed from several aspects, such as, serving only halal food and no alcohol, prayer room or prayer mat in each room, markers indicating directions of Mecca, Islamic arts and ambience, and a copy of the Quran in the hotel room.

Table 1: Islamic Tourism Definitions

\begin{tabular}{ll}
\hline \hline Author & Definition \\
\hline ITC - Malaysia (2015) & $\begin{array}{l}\text { Any activity, event, and experience undertaken in a state of travel } \\
\text { that is in accordance with Islam. }\end{array}$ \\
\hline Duman (2011) & $\begin{array}{l}\text { All tourism activities by Muslims that originates from Islamic } \\
\text { motivation and are realized according to Syariah principles. }\end{array}$ \\
\hline Henderson (2010) & $\begin{array}{l}\text { All product development and marketing efforts designed for and } \\
\text { directed at Muslims }\end{array}$ \\
\hline Hassan (2007) & The type of tourism that adheres to the value of Islam. \\
\hline Shakiry (2006) & $\begin{array}{l}\text { All forms of tourism, except those that go against Islamic } \\
\text { principles. }\end{array}$ \\
\hline \hline
\end{tabular}

In Japan, where the Muslim tourists is gaining in number,major airports are making prayer rooms available, while popular Japanese food such as Udon and Ramen are certified halal (HMJ, 2018). Thailand is also one of the countries that have taken the initiative to launch Muslim friendly application to help visitors to find hotels and shopping centre with prayer rooms and restaurants that provide halal food (Lefevre, 2015). To give assurance to their Muslim guest, Centara Hotel in Hatyai has obtained the Thailand prominent Halal Certification for its popular restaurant Saneha Cafe since 2014 (Centara, 2018). Similarly, the Aerostar Hotel in Moscow has adopted a Muslimfriendly approach as one of the hotel's kitchens is certified Halal and the hotel provides a copy of the Quran, a prayer mat and the Qibla direction in 20 of their rooms. The shampoo and soap provided in the rooms are also certified Halal and two separate prayer rooms are available; one for men and one for women (Sboros, 2014). In the Philippines, the Fairmont Makati and Raffles Makati hotels is also enhancing their Muslim friendly image by providing Quran copies, prayer room, and Arabic-language TV channels (Ocampo, 2014).

The few examples given above are actually indicators that the tourism industry is slowly recognizing the significance of halal tourism. This awareness must be complimented with reliable and updated knowledge and understanding about the Muslim consumer (tourist) behaviour and factors relevant in their decision-making process.

\subsection{Tourist Destination Loyalty}

Today's global tourism industry is extremely dynamic and competitive; compelling all destination managers to plan and strategize the marketing aspect of their destination management. They need a well-planned and carefully developed tourism product or destinations that would not only attracts, but more importantly retains its target market. The emphasis on destination loyalty is justified by the fact that success depends not only on the first purchase but on repurchase where a product or brand can survive over time. Studies have repeatedly showed that the most critical factor that could sustain market growth and business performance is by focusing on customer loyalty (Stepchenkova and Mills, 2010; Sun, Chi \& Xu, 2013; Wu, 2016). The conceptualization of destination loyalty 
has been discussed by several scholars in tourism studies which included both attitudinal and behavioural perspective (Gursoy, Chen, \& Chi, 2014; Tasci, 2017). The behavioural perspective focuses on tourist's repeat visitation within an appropriate timeframe (Oppermann, 2000; Alegre \&Juaneda, 2006; Sirikaya-Turk, Ekinci\& Martine, 2015), while the attitudinal perspective is reflected in behavioral intention to return to the destination, positive word-of-mouth, and recommendation (Castro, Armario, \& Ruiz, 2007; Chi \& Qu, 2008).

Therefore, it is vital for destination managers to understand what makes customers loyal to a destination and what their expectations are so that destinations can adapt their offerings, service delivery and communication strategies to meet and exceed customers' expectations.

\subsection{Destination Attributes}

Leiper (1995) explains that destinations are places towards which people travel and where they choose to stay for a while in order to experience certain features or characteristics - a perceived attraction of some sort. Cooper, Fletcher, Gilbert, Shepherd \&Wanhill (1998) define destinations as the focus of facilities and services designed to meet the needs of the tourists. Some studies have been conducted to identify the destination attributes that influence tourist visiting certain destinations. Eusebio\& Vieira (2011) conducted research on 923 visitors domestic and international tourists to build a sample that would be as representative as possible of the tourism market in the Central Region of Portugal. Zhou (2005), studied on price, culture, entertainment and relaxation, beautiful scenery, pleasant weather and climate, accessibility, safety, friendly attitude of local people toward tourists, and service as destination attributes elements. The sample of the study was selected at the Cape Town International Airport, after the international tourists finish their trip to Cape Town and are preparing for departure. Kaur, Chauhan \&Meduri (2016) found that local cuisine and food outlets, hotels and restaurants, famous handicraft and parking facilities are important destination attributes of Indian tourism destination.

In discussing travel destinations, Muslim scholars such as, Eid \& El-Gohary (2015), Al Jahwari (2015), and Battour, Ismail \&Battor (2011) proposes that Islamic physical attributes of destinations such as the inclusion of Halal food, prayer facilities, Islamic entertainment, Islamic dress codes, general Islamic morality and the Islamic call to prayer has positive effect on customer satisfaction. Battour, Ismail\& Battor (2011) and Abodeeb, Wilson, \& Moyle (2015) finds that the availability of Islamic norms and practices related to tourism at the destination like the lack of public consumption of alcohol and public gambling activities, general Islamic morality, and worship facilities are considered noteworthy for Muslim tourist. After considering these prior discussions, this study summarizes preferred destination attributes for Muslim travellers into two perspectives, which are religious related (availability of halal food and prayer facilities) and non-religious related (social-cultural attractions and safety-security) and are discussed in the following section.

\subsubsection{Availability of Halal Food}

Muslims are instructed by their religion to follow the regulations set out in the Quran with the need to recognize what food is permitted to be consumed (Tieman, 2013 ; Zailani, Kanapathy, Iranmesh, \& Tieman, 2015). The al Quran says, "And eat of the things which Allah has provided for you, lawful and good, and have Piety of Allah in Whom you believe" (5:88). Other verses from the Quran mentioning about the importance of lawful and good food include 2:172; 8:69; 16:114; 116; 
$6: 145 ; 5: 3-5$. Previous research have suggested that religious beliefs toward Halal (lawful and allowed) and Haram (forbidden) can influence Muslim's travel behaviour (Shakona et al. 2015; Shakona, 2013). According to Shafaei \& Mohamed (2015) as Muslims are required to stick and comply with Islamic values while travelling, the availability of Halal food is an important attribute that they search when choosing a travel destination. Thus, this study hypothesized that;

\section{$H_{1}$ : Availability of halal food has a significant influence on tourist satisfaction.}

\subsubsection{Prayer Facilities}

Muslims are required to dutifully perform their religious commitments in everyday life and also while travelling (Zamani-farahani \& Henderson, 2010) especially in order to perform prayer as stated in the Quran: "And be steadfast in prayer; practice regular charity; and bow down your heads with those who bow down in worship"(2:43). Other verse that instructs the obligation of Muslims to perform prayer includes $2: 3,45,153,238 ; 4: 101-103 ; 5: 55$. Study by Al-Hamarneh\& Steiner (2004) states that the prayer facility is one of the pivotal facilities for Muslims travellers. While according to Battour, Ismail, \& Battor (2011), easy access to places of worship (Masjid or prayer room) and availability of the Quran and the Qiblah direction pointer are highly prioritized tangible attributes for Muslim travellers. Later studies by Battour \& Ismail, (2015) and Abodeeb, Wilson, \& Moyle (2015) also found the similar finding. Thus, this study hypothesized that;

\section{$\mathrm{H}_{2}$ : Availability of prayer facilities has a significant influence on tourist satisfaction.}

\subsubsection{Socio-Cultural Factors}

Studies done by Funk and Bruun (2007); Kozak (2002); Maoz (2007) confirms that culture is one of the most important factor of tourist motivations when deciding their preferred travel destinations. Cultural tourism is essentially a form of tourism that focuses on the culture, and the cultural environments including landscapes of the destination, the values and lifestyles, heritage, visual and performing arts, industries, traditions, and leisure pursuits of the local destination or host community. It can include attendance at cultural events (festivals and performances), visits to museums and heritage places and mixing with local people (ICOMOS, 2002). It also includes travelling to or visiting of places or communities which are rich in a unique style that is representative of the ways of life of the people who live there, and which include both tangible and intangible resources (OECD, 2009). Studies have shown a rising trend of tourists seeking adventure, culture, history, archaeology and interaction with the local people (Hughes \& Allen, 2005; Nuryanti, 1996). The World Tourism Organization estimates that $40 \%$ of all international travel is based on cultural heritage attractions (UNWTO, 2005; Timothy \& Boyd, 2003). Sukanthasirikul\&Trongpanich(2016) explores the relationship between cultural tourism experience and customer satisfaction and concluded that tourism industry operators should direct their focus to both core service quality and also to peripheral services (such as costumes, dances, handicrafts, language, and other cultural activities). Thus, considering these previous studies it is hypothesized that;

$H_{3}$ : Destination social and cultural factors have a significant influence on tourist satisfaction. 


\subsubsection{Safety-Security While Visiting}

Safety and security is one of the most important factors that could influence quality in tourism. Tourists are more concern about these aspects before deciding to stay at any country. A safe and secure environment is a key to attracting any tourist to a destination. Previous studies reported a very high relationship between a safe travel environment and the number of tourist arrivals to a particular destination (MasterCard-Crescent Rating, 2015). The impact of the September 11 terrorist attacks on the USA in 2001 has changed the world tourism industry. Since then, the tourism industry experienced a big change in the traveling moods and patterns of international tourists. Non-Muslim tourists felt traveling to Muslim countries as a risk, whereas Arabs and Muslim communities felt being misunderstood and unwelcome in non-Muslim countries (AlHamarneh\& Steiner, 2004), especially in the USA, United Kingdom, Australia and the European nations where strict travel policies for Arab tourists exist (Shafaei\& Mohamed, 2015). Thus, this study hypothesized that;

$H_{4}$ : Destination safety and security factors have a significant influence on tourist satisfaction.

\subsection{Tourist Satisfaction}

Satisfaction is one of the most important elements that need to be considered by product and service provider. Kotler, Bowen, \& Makens (2006) emphasized that tourist satisfaction depends on degree of realised success in delivering the products and services in relation to tourist expectations. Only in the case that expectations are surpassed will the tourist be delighted. This approach in conceptualizing tourist satisfaction follows the Expectancy - Disconfirmation Theory (Oliver, 1993) which posits that customers form their satisfaction with a target product or service as a result of subjective comparisons between their expectations and perceptions. Knowledge of customer expectations and requirement is essential because it provide understanding of how customers define quality of service and facilitates the development of a more specific customer satisfaction measurement instruments (Hayes, 1997).

While tourists' overall satisfaction is reported to be the most important predictor of destination loyalty (Chi and Qu, 2008; Neal and Gursoy, 2008), there are also studies that acknowledged its mediating role in the comprehensive theoretical framework (Su, Cheng, and Huang, 2011; MiguelDa'vila, Cabeza-Garci'a, Valdunciel, \&Flo' rez, 2010). This would mean that destination attributes has an indirect effect on tourist destination loyalty through satisfaction. Thus this study hypothesized that;

H5: Tourist satisfaction has a significant influence on destination loyalty.

$H_{6-} H_{9:}$ The impact of both religious and non-religious destination attributes on destination loyalty is mediated by tourist satisfaction. 


\section{METHODOLOGY}

\subsection{Population and Sampling Procedure}

The population of this study are Muslim travellers that have at least visited one foreign non-Muslim majority country either on their own or with a tour operator. A purposive sampling technique was used, where samples are intercepted at the Penang International Airport and was asked a screening question to determine their suitability as respondents for the study. They were also required to reflect a non-Muslim majority country that they have visited before going on to answering the questionnaire. After a week at the airport, a total of 110 questionnaire sets were successfully collected for the study.

\section{ANALYSIS AND FINDINGS}

In this study, the researcher employs structural equation modelling approach for data analysis and testing of the proposed model. Specifically, this study chose to use variance-based SEM a.k.a. partial least squares SEM (PLS-SEM) due to its nature of small sample size. 110 sets of questionnaires were collected but after further evaluation and deletion for outlier, only 86 were fit to be used in the analysis for this study. Estimation of the adequateness of the sample size using the $G^{*}$ Power software with four exogenous variables in the proposed structural model suggest that a minimum of 85 sample is required given a medium effect size $f^{2}=0.15$, power $(1-\beta)=0.80$ and $\alpha=0.05$ (Faul, Erdfelder, Buchner and Land, 2009). The PLS-SEM analysis was carried out using SmartPLS 3.0 software (Ringle, Wende\& Becker, 2015). Like covariance-based SEM, the PLSSEM also is a two-stage process; assessment of measurement model and evaluation of structural model. In the first stage, the measurement model was carried out to assess its validity and reliability before continuing with testing the proposed hypothesis in the second stage through the evaluation of structural model path analysis.

\subsection{Measurement Model}

The measurement model was first examined for its internal consistency reliability and convergent validity through the measures of items factor loadings, composite reliability (CR) and average variance extracted (AVE). As suggested by Hair et al. (2013), a model is said to have internal consistency reliability if the CR values for each latent construct are well above 0.7. In addition, they also stated that model with latent construct AVE above 0.5 is considered to meet the convergent validity assumption. For this study, all the latent constructs under evaluation CR and AVE values are well above the cut-off values such that the CR values ranges between 0.834 until 0.968 and the AVE values were between 0.559 and 0.885 . Hair et al. (2013) also suggested that the indicator's outer loading should be above 0.708 and anything below the value should be considered for removal from the model. For this study, three items were removed due to low factor loadings (below 0.5) which resulted in low AVE value. However, other items which has loadings higher than 0.6 but lower than 0.708 were retain since the AVE for the construct they belong to has already achieved the convergent validity assumption. These results were summarized and reported in Table 2 and Figure 2. 
Table 2: Factor Loading, Composite Reliability (CR), and Average Variance Extracted (AVE) of the Measurement Model

\begin{tabular}{lccccc}
\hline \hline Construct & Item & Loadings & $\begin{array}{c}\text { Indicator } \\
\text { Reliability }\end{array}$ & CR $^{\mathbf{a}}$ & AVE $^{\mathbf{b}}$ \\
\hline Halal Facility (HF) & HF1 & 0.959 & 0.920 & 0.968 & 0.885 \\
& HF2 & 0.972 & 0.945 & & \\
& HF3 & 0.967 & 0.935 & & \\
& HF4 & 0.860 & 0.740 & & 0.650 \\
Prayer Facility (PF) & PF1 & 0.900 & 0.810 & 0.880 & \\
& PF2 & 0.899 & 0.808 & & \\
& PF3 & $\mathbf{0 . 6 4 7}$ & 0.419 & & \\
& PF4 & 0.751 & 0.564 & & \\
Safety \& Security & SS1 & 0.771 & 0.594 & 0.904 & \\
(SS) & SS2 & 0.864 & 0.746 & & \\
& SS3 & 0.862 & 0.743 & & \\
& SS4 & 0.854 & 0.729 & & \\
\hline Social \& Cultural & SCF3 & $\mathbf{0 . 6 9 1}$ & 0.477 & 0.834 & \\
(SCF) & SCF5 & 0.754 & 0.569 & & \\
& SCF6 & 0.853 & 0.728 & & \\
& SCF7 & $\mathbf{0 . 6 7 9}$ & 0.461 & & \\
\hline Tourist Satisfaction & TS1 & 0.775 & 0.601 & 0.871 & \\
(TS) & TS2 & 0.777 & 0.604 & & \\
& TS3 & 0.786 & 0.618 & & \\
& TS4 & 0.830 & 0.689 & & \\
\hline Destination Loyalty & DL1 & 0.924 & 0.854 & 0.910 & \\
(DL) & DL2 & $\mathbf{0 . 6 5 7}$ & 0.432 & & \\
& DL3 & 0.865 & 0.748 & & \\
& DL4 & 0.922 & 0.850 & & \\
\hline \hline
\end{tabular}

aComposite reliability $(\mathrm{CR})=$ (square of the summation of the factor loadings) $/\{$ (square of the summation of the factor loadings) $\mathrm{x}$ (square of the summation of the error variances) $\}$

bAverage variance extracted $(\mathrm{AVE})=($ summation of the square of the factor loadings $) /$ \{ (summation of the square of the factor loadings) $\mathrm{x}$ (summation of the error variances) $\}$

The second part of measurement model checking procedure is to check for its discriminant validity. For this study, three criteria were used to assess the model discriminant validity which are FornellLarcker, cross loading, and heterotrait-monotrait (HTMT) ratio. Table 3 shown below represent the Fornell-Larcker criterion for assessing the model discriminant validity. Based on the table above, it is said to have not violated the discriminant validity assumption if the diagonal values are well above all other values to the left and below it, or in other words, the latent variable correlation should be higher when correlate with itself as compared to its correlation with other variables (Ramayah, Yeap\&Igatius, 2013, p. 142). Thus, based on the Fornell-Larcker criterion shown in Table 3, the model met the discriminant validity assumption since all the diagonal values representing the square root AVE for each of the latent construct are higher that the its correlation coefficients with other variables (Fornell\&Larcker, 1981). 
Figure 2: Final Measurement Model after Item Deletion

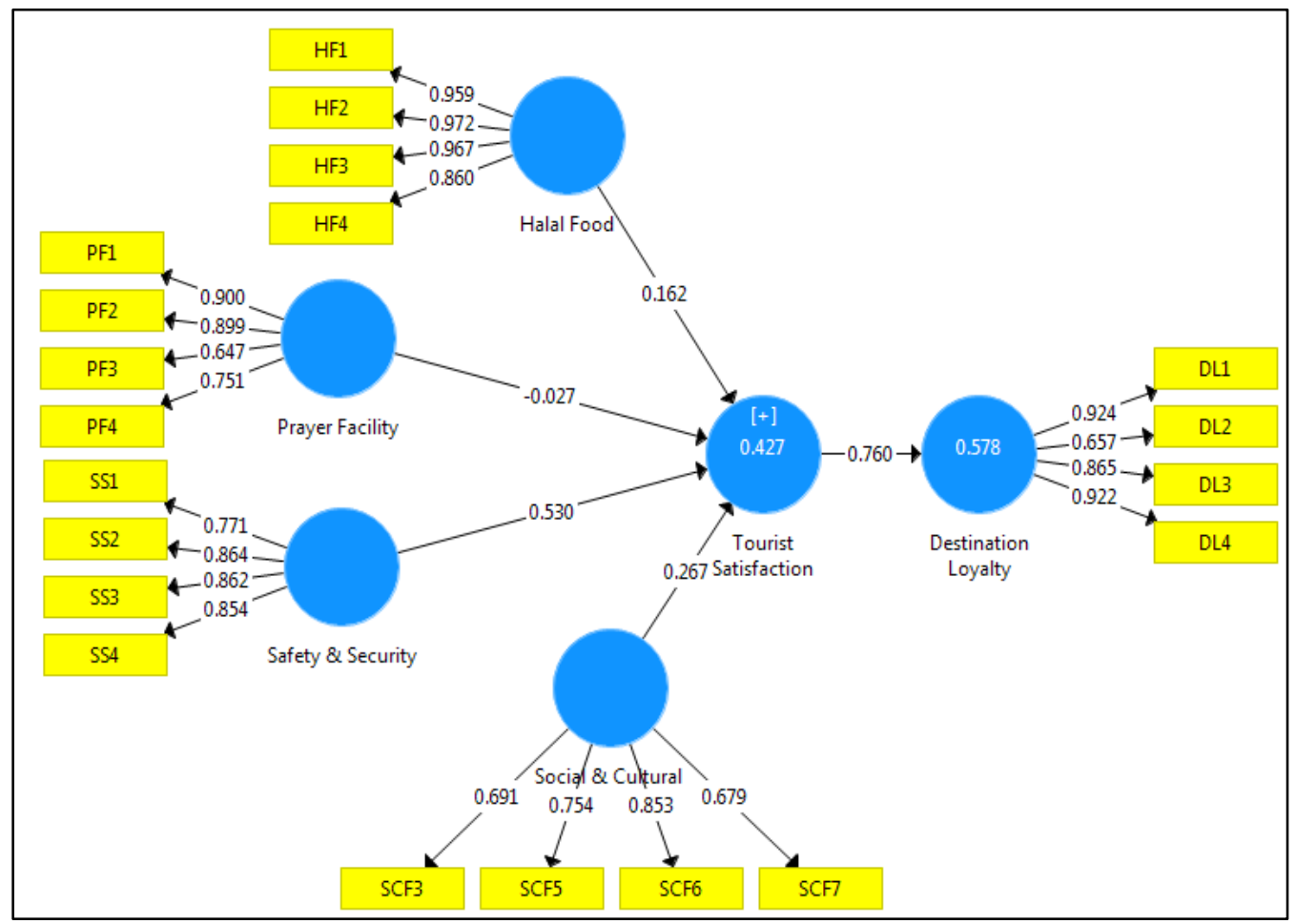

The discriminant validity was also assessed through items cross loading (Table 4). Comparing factor loading between the construct, in order for each construct to be distinct with each other and achieved discriminant validity assumption, the loadings gap between the constructs should be at least 0.1 and preferably greater than 0.2 (Hair et. al, 2013). Examining Table 4 for any existence of cross loading problem shows that most of the loadings gaps are greater than preferable value 0.2 , and only four items (DL3, SS1, TS1, and TS3), has loading gaps less than 0.2 but still meet the minimum required gap of 0.1 . Thus, Table 4 further support the Fornell-Larcker criterion discussed above on the assessment of discriminant validity for the proposed model.

Finally, to improve the rigorousness of the statistical analysis, an alternative approach for assessing the discriminant validity was also employed in this study. As stated by Henseler, Ringle\&Sarstedt (2015), heterotrait-monotrait ratio of correlation (HTMT) is a relatively new criterion for assessing discriminant validity that outperform the classical method using Fornell-Larcker criterion and cross loading. The result of this method is presented in Table 5. Based on the result presented, it shows that the HTMT ratio between Tourist Satisfaction (TS) and Destination Loyalty (DL) violate the classical approach HTMT.85 which could indicate that there is a possible problem in discriminant validity. However, a more liberal approach HTMT.90 and HTMT (Inference) do not show any violation of discriminant validity for the proposed model.

Thus, based on the three-criterion used for assessing model discriminant validity, we can conclude that the proposed model shows the existence of discriminant validity. 
Table 3: Fornell-Larcker Criterion Discriminant Validity for the Measurement Model

\begin{tabular}{lcccccc}
\hline \hline & {$[1]$} & {$[2]$} & {$[3]$} & {$[4]$} & {$[5]$} & [6] \\
\hline [1] Halal Facility & $\mathbf{0 . 9 4 1}$ & & & & & \\
[2] Prayer Facility & 0.409 & $\mathbf{0 . 8 0 7}$ & & & & \\
[3] Service Security & 0.298 & 0.299 & $\mathbf{0 . 8 3 9}$ & & & \\
[4] Social \& Culture Facility & -0.128 & 0.107 & 0.074 & $\mathbf{0 . 7 4 8}$ & & \\
[5] Tourist Satisfaction & 0.275 & 0.226 & 0.590 & 0.282 & $\mathbf{0 . 7 9 2}$ & \\
[6] Destination Loyalty & 0.333 & 0.263 & 0.566 & 0.291 & 0.760 & $\mathbf{0 . 8 4 9}$ \\
\hline \hline
\end{tabular}

Diagonal elements are the square roots of the AVE while the off diagonals are the correlations between constructs

Table 4: Cross Loading For Items in the Measurement Model

\begin{tabular}{cccccccc}
\hline \hline Construct & Item & DL & HF & PF & SS & SCF & TS \\
\hline Destination & DL1 & $\mathbf{0 . 9 2 4}$ & 0.299 & 0.232 & 0.497 & 0.227 & 0.698 \\
Loyalty & DL2 & $\mathbf{0 . 6 5 7}$ & 0.122 & 0.301 & 0.390 & 0.323 & 0.453 \\
& DL3 & $\mathbf{0 . 8 6 5}$ & 0.364 & 0.216 & 0.499 & 0.190 & 0.697 \\
& DL4 & $\mathbf{0 . 9 2 2}$ & 0.302 & 0.180 & 0.527 & 0.287 & 0.696 \\
\hline Halal & HF1 & 0.303 & $\mathbf{0 . 9 5 9}$ & 0.406 & 0.274 & -0.161 & 0.281 \\
Facility & HF2 & 0.298 & $\mathbf{0 . 9 7 2}$ & 0.375 & 0.233 & -0.147 & 0.221 \\
& HF3 & 0.338 & $\mathbf{0 . 9 6 7}$ & 0.370 & 0.289 & -0.127 & 0.252 \\
& HF4 & 0.308 & $\mathbf{0 . 8 6 0}$ & 0.379 & 0.313 & -0.050 & 0.269 \\
\hline Prayer & PF1 & 0.267 & 0.398 & $\mathbf{0 . 9 0 0}$ & 0.293 & 0.066 & 0.230 \\
Facility & PF2 & 0.221 & 0.355 & $\mathbf{0 . 8 9 9}$ & 0.222 & 0.109 & 0.225 \\
& PF3 & 0.162 & 0.242 & $\mathbf{0 . 6 4 7}$ & 0.232 & 0.053 & 0.036 \\
& PF4 & 0.163 & 0.276 & $\mathbf{0 . 7 5 1}$ & 0.260 & 0.124 & 0.101 \\
\hline Social \& & SCF3 & 0.224 & -0.118 & 0.066 & 0.026 & $\mathbf{0 . 6 9 1}$ & 0.168 \\
Cultural & SCF5 & 0.151 & -0.165 & 0.027 & 0.062 & $\mathbf{0 . 7 5 4}$ & 0.166 \\
& SCF6 & 0.315 & -0.031 & 0.157 & 0.168 & $\mathbf{0 . 8 5 3}$ & 0.276 \\
& SCF7 & 0.144 & -0.114 & 0.033 & -0.077 & $\mathbf{0 . 6 7 9}$ & 0.205 \\
\hline Safety \& & SS1 & 0.581 & 0.319 & 0.250 & $\mathbf{0 . 7 7 1}$ & 0.102 & 0.483 \\
Security & SS2 & 0.495 & 0.317 & 0.234 & $\mathbf{0 . 8 6 4}$ & 0.046 & 0.540 \\
& SS3 & 0.421 & 0.227 & 0.239 & $\mathbf{0 . 8 6 2}$ & 0.050 & 0.495 \\
& SS4 & 0.394 & 0.121 & 0.284 & $\mathbf{0 . 8 5 4}$ & 0.049 & 0.453 \\
\hline Tourist & TS1 & 0.647 & 0.292 & 0.318 & 0.591 & 0.162 & $\mathbf{0 . 7 7 5}$ \\
Satisfaction & TS2 & 0.509 & 0.148 & 0.129 & 0.429 & 0.243 & $\mathbf{0 . 7 7 7}$ \\
& TS3 & 0.628 & 0.175 & 0.153 & 0.445 & 0.219 & $\mathbf{0 . 7 8 6}$ \\
& TS4 & 0.606 & 0.238 & 0.092 & 0.382 & 0.281 & $\mathbf{0 . 8 3 0}$ \\
\hline \hline
\end{tabular}

$D L=$ Destination Loyalty; $H F=$ Halal Facility; $P F=$ Prayer Facility; $S C F=$ Social \& Cultural; SS = Safety \& Security; TS $=$ Tourist Satisfaction 
Table 5: Heterotrait-Monotrait(HTMT) Result

\begin{tabular}{|c|c|c|c|c|c|c|}
\hline \multirow{2}{*}{ [1] HF } & [1] & [2] & [3] & [4] & [5] & [6] \\
\hline & & & & & & \\
\hline [2] PF & $\begin{array}{c}0.424 \\
(0.267,0.577)\end{array}$ & & & & & \\
\hline [3] SS & $\begin{array}{c}0.321 \\
(0.173,0.493)\end{array}$ & $\begin{array}{c}0.358 \\
(0.171,0.563)\end{array}$ & & & & \\
\hline [4] SCF & $\begin{array}{c}0.189 \\
(0.111,0.383)\end{array}$ & $\begin{array}{c}0.152 \\
(0.138,0.377)\end{array}$ & $\begin{array}{c}0.161 \\
(0.141,0.385)\end{array}$ & & & \\
\hline [5] TS & $\begin{array}{c}0.304 \\
(0.150,0.496)\end{array}$ & $\begin{array}{c}0.239 \\
(0.176,0.400)\end{array}$ & $\begin{array}{c}0.700 \\
(0.562,0.821)\end{array}$ & $\begin{array}{c}0.359 \\
(0.210,0.575)\end{array}$ & & \\
\hline [6] DL & $\begin{array}{c}0.352 \\
(0.196,0.527) \\
\end{array}$ & $\begin{array}{c}0.303 \\
(0.165,0.472) \\
\end{array}$ & $\begin{array}{c}0.655 \\
(0.516,0.779)\end{array}$ & $\begin{array}{c}0.368 \\
(0.244,0.568)\end{array}$ & $\begin{array}{c}0.896 \\
(0.797,0.975)\end{array}$ & \\
\hline
\end{tabular}

The one results marked in bold indicate discriminant validity problems according to the HTMT.85 criterion, while HTMT.90(in parenthesis) criterion and HTMT $T_{\text {inference }}$ does not indicate discriminant validity problems in this example

\subsection{Structural Model}

The second stage of PLS-SEM is to examine the structural model and test the hypothesis proposed earlier. At this stage, bootstrapping procedure was employed to examine the structural model path coefficients for their significant effectto test whether the hypothesis related to a specific path is supported or not. In addition, the $R^{2}$ values for the endogenous latent constructs were also examined to determine how well the data fit the proposed model and how much variance in the endogenous constructs can be explain by the combination of all the proposed exogenous constructs existed in the model (Chin, 1998). Chin (1998) also suggested that we used bootstrapping method with at least 1000 resampling to test the significance of the structural model path. However, in this study we used bootstrapping procedure with 5000 resampling following the recent study by Hair et al. (2017). To achieve a significant path, we employed a directional hypothesis test using $t$ statistic such that the path estimate is significant if its $t$ values calculated from the bootstrapping procedure were greater than the critical value $t=1.645$. Figure 3, Table 6 , and Table 7 summarize the result obtain from the bootstrapping procedure. Table 6 presented the direct effect from all four-exogenous variable (HF, PF, SS, and SCF) to the mediator variable TS, and the direct effect from the mediator to the endogenous variable DL. For each of the direct effect path, the standardized beta coefficients were reported together with its respective standard error value, $t$ statistics and the effect size $f^{2}$. In addition, Table 6 also provided the endogenous variables' coefficient of discriminant value, $R^{2}$ and the Stone-Geisser $Q^{2}$ predictive relevance coefficients. 
Figure 3: Structural Model (Bootstrapping result)

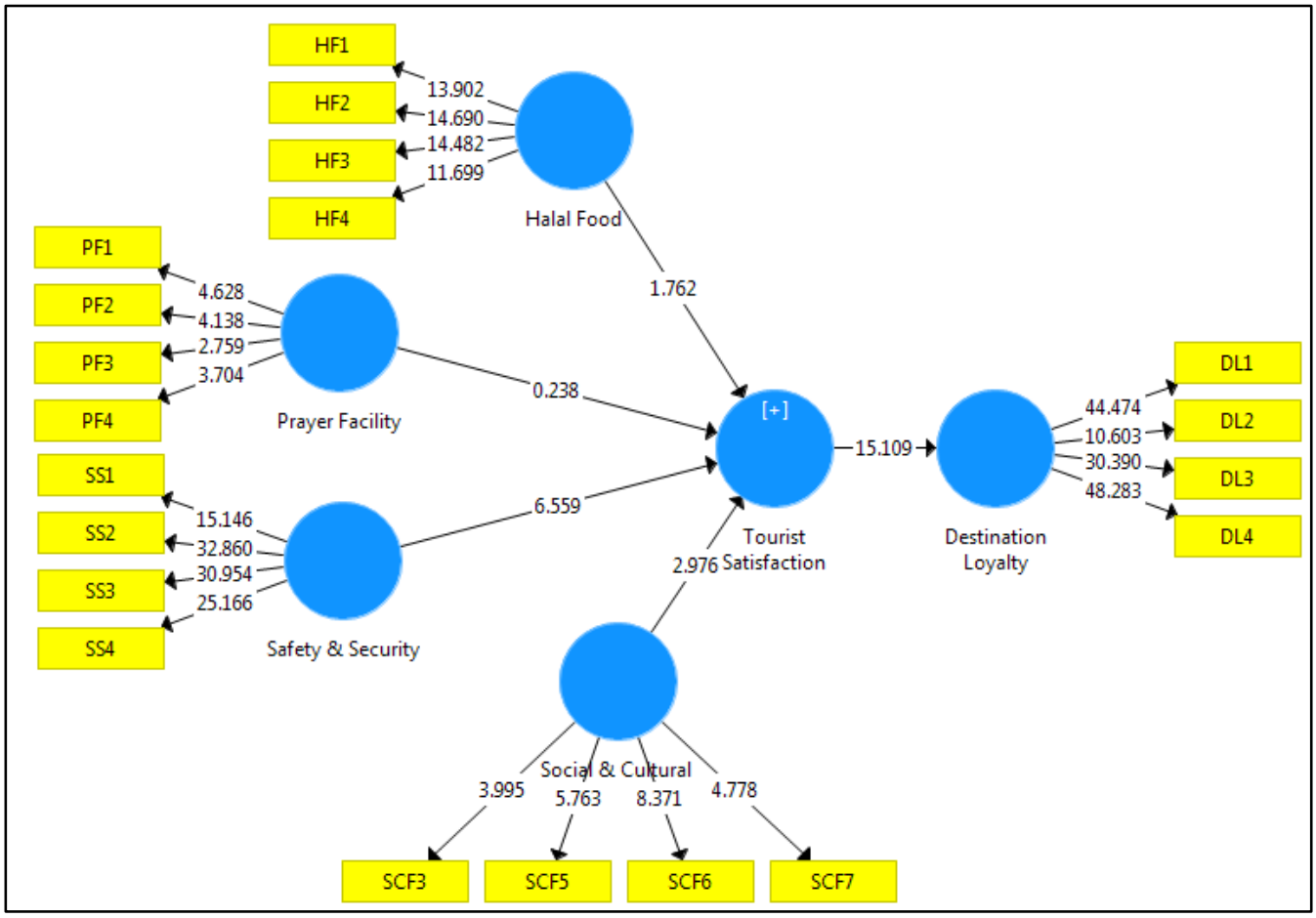

Table 6: Result Summary on Direct Path Analysis of the Structural Model

\begin{tabular}{ccccccccc}
\hline \hline Hypothesis & Relationship & $\begin{array}{c}\text { Std. } \\
\text { Beta }\end{array}$ & $\begin{array}{c}\text { Std. } \\
\text { Error }\end{array}$ & t-value & Decision & $\mathbf{R}^{2}$ & $\mathbf{Q}^{2}$ & $\mathbf{f}^{2}$ \\
\hline $\mathrm{H}_{1}$ & $\mathrm{HF} \rightarrow \mathrm{TS}$ & 0.162 & 0.092 & $1.762^{*}$ & Supported & 0.427 & 0.231 & 0.035 \\
$\mathrm{H}_{2}$ & $\mathrm{PF} \rightarrow \mathrm{TS}$ & -0.027 & 0.114 & 0.238 & $\begin{array}{c}\text { Not } \\
\text { Supported }\end{array}$ & & 0.001 \\
$\mathrm{H}_{3}$ & $\mathrm{SS} \rightarrow \mathrm{TS}$ & 0.530 & 0.081 & $6.559^{* *}$ & Supported & & & 0.425 \\
$\mathrm{H}_{4}$ & $\mathrm{SCF} \rightarrow \mathrm{TS}$ & 0.267 & 0.090 & $2.976^{* *}$ & Supported & & & 0.118 \\
$\mathrm{H}_{5}$ & $\mathrm{TS} \rightarrow \mathrm{DL}$ & 0.760 & 0.050 & $15.109^{* *}$ & Supported & 0.528 & 0.375 & 1.369 \\
\hline \hline
\end{tabular}

**p $<0.01,{ }^{*} \mathrm{p}<0.05$

Based on the result presented in Table 6, Halal Facilities, Safety and Security, and Social and Cultural explain $42.7 \%$ variation in Tourist Satisfaction while the combination of Halal Facility, Safety and Security, and Social and Cultural, together with Tourist Satisfaction combined explain $52.8 \%$ of the variability in Destination Loyalty among the respondent surveyed. According to Chin et al. (2008) about model validity based on the $R^{2}$ value, the $R^{2}$ value for both endogenous variable Tourist Satisfaction and Destination Loyalty can be considered to have moderate to strong model validity. Testing the hypothesis for the direct effect relationship shows that all $\left(\mathrm{H}_{1}, \mathrm{H}_{3}, \mathrm{H}_{4}\right.$, and $\left.\mathrm{H}_{5}\right)$ except one $\left(\mathrm{H}_{2}\right)$ of the direct effect path coefficients were positively significant and supported the proposed hypothesis set earlier. $\mathrm{H}_{1}$ result provided in Table 6 conclude that there is enough 
evidence to support the hypothesis that Halal Facility has a significant positive influence towards Tourist Satisfaction $(\beta=0.162, p<0.05)$. Similarly, $\mathrm{H}_{3}$ shows that there is a positive significance influence between safety and security with tourist satisfaction $(\beta=0.530, p<0.01)$. $\mathrm{H}_{4}$ test the influence of social and cultural toward tourist satisfaction and it is found that there is enough evidence to support the existence of direct positive influence of social and cultural on tourist satisfaction $(\beta=0.267, p<0.01)$. Table 6 also support the existence of direct positive influence of tourist satisfaction on destination loyalty $(\beta=0.760, p<0.01)$. Further examination on the result obtain indicate that safety and security is the most dominant factor that influence tourist satisfaction. The effect size $f^{2}$ for significant exogenous variables ranges from 0.035 until 0.425 which can be considered as moderate to strong effect size as stated by Cohen (1988). Finally, Table 6 also reported the Stone-Geiser $Q^{2}$ value that were obtained from the blindfolding procedure run using SmartPLS 3.0. The Stone-Geiser $Q^{2}$ value is another measure that can be used to explain the model fit (Stone, 1974; Geiser, 1974). Based on Cohen (1988) guidelines on various statistical effect size, an effect size of 0.02 is small effect size, 0.15 is medium effect size and 0.35 is large effect size. In addition, an endogenous $Q^{2}$ value greater than 0 is said to have the relevance predictive of the given endogenous variable and a $Q^{2}$ value of 0 or negative is considered to have lack of predictive relevance of the given endogenous variable. In this study, both endogenous latent constructs, Tourist Satisfaction and Destination Loyalty, both have $Q^{2}$ values of 0.231 and 0.375 respectively. Since both values are positive, thus the proposed PLS-SEM model is predictive of the endogenous variables and has a medium to large effect size.

In this study, the indirect effect was also tested for the influence of four exogenous variables (halal facility, prayer facility, safety and security, social and cultural) on the endogenous variable (destination loyalty) is mediated by tourist satisfaction. Table 7 provides the summarized result obtained from this analysis. It is found that there is enough evidence to support the hypothesis that the influence of halal facility, safety and security, and social and cultural on destination loyalty is mediated by tourist satisfaction. However, availability of prayer facility is found to have no significant influence on tourist satisfaction (mediator) and destination loyalty.

Table 7: Result on Indirect Path Analysis (Mediating Effect) of the Structural Model

\begin{tabular}{cccccc}
\hline \hline Hypothesis & Path & Std. Beta & SE $_{\text {Beta }}$ & t-value & Decision \\
\hline $\mathrm{H}_{6}$ & $\mathrm{HF} \rightarrow \mathrm{TS} \rightarrow \mathrm{DL}$ & 0.123 & 0.071 & $1.740^{*}$ & Supported \\
$\mathrm{H}_{7}$ & $\mathrm{PF} \rightarrow \mathrm{TS} \rightarrow \mathrm{DL}$ & -0.021 & 0.085 & 0.241 & Not Supported \\
$\mathrm{H}_{8}$ & $\mathrm{SS} \rightarrow \mathrm{TS} \rightarrow \mathrm{DL}$ & 0.403 & 0.073 & $5.537^{* *}$ & Supported \\
$\mathrm{H}_{9}$ & $\mathrm{SCF} \rightarrow \mathrm{TS} \rightarrow \mathrm{DL}$ & 0.203 & 0.070 & $2.894^{* *}$ & Supported \\
\hline \hline
\end{tabular}

$* * \mathrm{p}<0.01, * \mathrm{p}<0.05$

\section{ANALYSIS AND FINDINGS}

The objective of this study is to appreciate what is considered significant for Muslims when experiencing a tour to non-Muslim majority country. The reason for exploring the non-Muslim majority travel destinations is due to the fact that it has become one of the favoured destinations for Muslim tourism market segment. However, there is an assumption that we would like to highlight when we refer to the Muslim market segment. From a marketing perspective, we would have to agree that the Muslim community itself is diverse, not only between countries but also 
within a particular country (example; Malaysia). As such, generalizing any community on religious pretext as being thoroughly homogenous is inaccurate, either from the perspective of religious practices or a persons' religiosity. This study has shown that apart from the religious requirements during a travel, the practical and core reasons of a social visit are still quite similar as to any other tourist market segments; that is, the experiencing of new social-cultural events with assured safetysecurity. From the data analysis, the most important destination attribute is ensuring one's own safety-security during the visit. The need to ensure safety-security is of course a reflection of the person's perception toward risk. For Muslims, this feeling of insecurity or risk during international travel could be justified by the portrayal of Islamophobia in the international media. As such, all the stakeholders relevant to the Muslim tourism market segment have to be explicit in reassuring this fear or anxiety when offering their travel or tourism products. The role of credibility and trustworthiness of those involved in the tourism industry (tour operator, hotels, etc.) is crucial in addressing this security-safety factor.

As could be observed from the data analysis, the religious components of the travel destination attributes have provided mixed, though not thoroughly unexpected result. As for availability of halal food, the influence over tourist satisfaction is not as strong as the two destination attribute discussed earlier. Halal food does not certainly mean gourmet like cuisine. In fact where food is concern the Quran stated, "... and eat and drink but waste not by extravagance, certainly Allah likes not those who waste by extravagance" (7:31). Allah's Messenger (pbuh) said: "We are a people who do not eat until we are hungry. And if we eat, we do not eat to our fill'. But still, even as lesser devout Muslims, having stronger feeling over what is consumed is something very much expected of, over other religious obligations.

Although MasterCard and CrecentRating (2016) puts prayer facility as a "need to have" rating for Muslim travellers, the data analysis from this study found it having no significant influence over tourist satisfaction. This contradiction is not totally unexpected taking into consideration the element of flexibility in performing the prayers (solat) especially as musafir (travellers). The Quran says, "And when you travel throughout the land, there is no blame upon you for shortening the prayer" (4:101). Apart from the flexibility in prayers (solat) allowed for travellers, two other factors might also justify the data analysis outcome. Firstly, compared to the circumstances during travel, the act of solat is performed on totally different foundation. The al Quran says, "So from wherever you go out (for prayer, O Muhammad) turn your face toward al-Masjid al-Haram, and indeed, it is the truth from your Lord. And Allah is not unaware of what you do" (2:149). As such, Muslims performing the solat is not at all restricted by any physical encumbrances. Secondly, the prayer facilities (qiblat and prayer time) as mentioned in the rating are too trivial for a Muslim performing the solat and can in fact be easily available on modern electronic and communication devices. There is also an earlier study by Nassar, Mostafa, \& Reisinger, (2015), which found that the availability of Muslim-oriented amenities and services such as praying facilities is not important factor that determines Muslims go to travel.

In conclusion, the knowledge about tourism destination attributes and how it could affect Muslim travellers need to be translated into systematic and effective marketing strategies for tourism industry stakeholders. However, as mentioned earlier, an element that must be taken into consideration is the diverse nature of the Muslim tourist market segment. Future studies should explicitly include existing demographic and social diversity in the Muslim community as moderating the eventual relationship between destination attributes and tourist satisfaction. 


\section{REFERENCES}

Abodeeb, J., Wilson, E., \& Moyle, B. (2015). Shaping destination image and identity: Insights for Arab tourism at the Gold Coast, Australia. International Journal of Culture, Tourism, and Hospitality Research, 9(1), 6-21.

Al Jahwari, D. S. (2015). An Integrative Model of Muslim Students' Religiosity and Travelling Behaviour to Gaming Destinations (Dissertation: University of South Carolina, USA).

Al-Hamarneh, A., \& Steiner, C. (2004). Islamic tourism: Rethinking the strategies of tourism development in the Arab world after 11 September. Comparative Studies of South Asia, Africa and the Middle East, 24(1),173-182.

Alegre, J., \& Juaneda, C. (2006). Destination loyalty. Consumers' economic behavior'. Annals of Tourism Research, 33(3), 684-706.

Battour, M., \& Ismail, M. N. (2015). Halal tourism: Concepts, practises, challenges and future. Tourism Management Perspectives, 9, 150-154.

Battour, M., Ismail, M. N., \& Battor, M. (2011). The impact of destination attributes on Muslim tourist's choice. International Journal of Tourism Research, 13(6), 527-540.

Castro,C. B., Armario, E. M., \& Ruiz, D. M. (2007). The influence of market hetero-geneity on the relationship between a destination's image and tourists' future behavior. Tourism Management, 28(1),175-187.

Centara (2018). Centara Hotel and Resort, Media Centre. (www.centarahotelsresorts.com/mediacentre/news-people-csr/910-centara-hotel-hat-ya/)

Chi, C. G. Q., \& Qu, H. (2008). Examining the structural relationships of destination image, tourist satisfaction and destination loyalty: An integrated approach. Tourism Management, 29(4), 624-636.

Chin, W. W. (1998), Issues and opinions on structural equation modeling. MIS Quarterly, 22(1), 7-16.

Chin, W. W., Peterson, R. A., \& Brown, S. P. (2008). Structural equation modeling in marketing: some practical reminders. The Journal of Marketing Theory and Practice, 16(4), 287-298.

Cohen, J. (1988). Statistical power analysis for the behavioral sciences. Mahwah, NJ: Lawrence Erlbaum.

Cooper, C., Fletcher, J., Gilbert, D., Shepherd, R., \&Wanhill, S. (ed.). (1998). Tourism: Principles and Practices, (2nd ed.). England: Addison-Wesley, Longman.

Dinar Standard (2018). State of the Global Islamic Economy Report 2015. (Accessed through website: $h t t p: / / w w w$. dinarstandard.com/)

Duman, T. (2011). Value of Islamic Tourism Offering: Perspectives from the Turkish Experience. In World Islamic Tourism Forum (WITF, 2011), Kuala Lumpur, Malaysia.

Eid, R., \& El-Gohary, H. (2015). The role of Islamic religiosity on the relationship between perceived value and tourist satisfaction. Tourism Management, 46, 477-488.

El-Gohary, H. (2016). Halal tourism, is it really Halal? Tourism Management Perspectives, 19, 124-130.

Eusebio, C., \& Vieira A. L. (2011). Destination attributes' evaluation, satisfaction and behavioral intentions: A structural modeling approach. International Journal of Tourism Research. 15(1), 66-80.

Funk, D. C., \& Bruun, T. J. (2007). The role of socio-psychological and culture-education motives in marketing international sport tourism: A cross-cultural perspective. Tourism Management, 28(3), 806-819. 
Faul, F., Erdfelder, E., Buchner, A., Lang, A. G. (2009). Statistical power analyses using G*Power 3.1: Tests for correlation and regression analyses. Behavior Research Methods, 41(4), 1149-1160.

Fornell, C., Larcker, D.F. (1981). Evaluation structural equation models with unobservable variables and measurement error. Journal of Marketing, 18(1), 39-50.

Geisser, S. (1974). A predictive approach to the random effects model. Biometrika, 61(1), 101-107.

Gursoy, D., Chen, J.S., \& Chi, C.G. (2014). Theoretical examination of destination loyalty formation. International Journal of Contemporary Hospitality Management, 26(5), 809827.

Hair, J. F., Hult, G. T. M., Ringle, C., \& Sarstedt, M. (2017). A Primer on Partial Least Squares Structural Equation Modeling (PLS-SEM), 2 ${ }^{\text {nd }}$ Edition. Thousand Oaks: Sage Publications.

Hair, J. F., Hult, G. T. M., Ringle, C., \& Sarstedt, M. (2013). A Primer on Partial Least Squares Structural Equation Modeling (PLS-SEM). Thousand Oaks: Sage Publications.

Hassan, A. R. (2007). Islamic tourism revisited. Islamic Tourism, 32(2).

Henderson, J. C. (2010). Sharia-compliant hotels. Tourism and Hospitality Research, 10(3), 246254.

Henseler, J., Ringle, C. M., \& Sarstedt, M. (2015). A new criterion for assessing discriminant validity in variance-based structural equation modeling. Journal of the Academy of Marketing Science, 43(1), 115-135.

HMJ. (2018). Halal Media Japan - Halal and Muslim-friendly Information - www.halalmedia.jp

Hughes, H., \& Allen, D. (2005). Cultural tourism in central and Eastern Europe: The views of induced image formation agents. Tourism Management, 26(2), 173-183.

ICOMOS (2002), International Cultural Tourism Charter, Paris.

ITC. (2015). Malaysia Islamic Tourism - Facts and Figure. Islamic Tourism Centre, Ministry of Tourism and Culture, Malaysia.

Kaur. A, Chauhan. A, \& Medury, Y. (2016). Destination image of Indian tourism destinations an evaluation using correspondence analysis. Asia Pasific Journal of Marketing and Logistics, 28(3), 499-524.

Kotler, P., Bowen, J. T., \& Makens, J. C. (2006).Marketing for hospitality and tourism 4, Prentice Hall, United Kingdom.

Kozak, M. (2002). Comparative analysis of tourist motivations by nationality and destinations. Tourism Management, 23(3), 221-232.

Leiper, N. (1995). Tourism Management. Melbourne: RMIT Press.

Lefevre, A. S. (2015). Thailand launches Muslim friendly apps. Reuters. Retrieved fromhttps://www.reuters.com/article/us-thailand-tourism/thailand-launches-muslimfriendly-tourist-app-idUSKCN0P918F20150629

Lipka,M., \& Hackett, C. (2017). Why Muslims are the world's fastest-growing religious group? Pew Research Center. Retrieved from https://www.pewresearch.org/facttank/2017/04/06/why-muslims-are-the-worlds-fastest-growing-religious-group/

MasterCard-Crescent Rating (2015) Global Muslim Travel Index (GMTI March, 2015)

Maoz, D. (2007). Backpackers' motivations the role of culture and nationality. Annals of Tourism Research, 34(1), 122-140.

Miguel-Davila, J. A., Cabeza-Garcia, L., Valdunciel, L., \& Flo'rez, M. (2010). Operations in banking: The service quality and effects on satisfaction and loyalty. The Service Industries Journal, 30(13), 126-139. 
Mohsin, A., Ramli, N., \& Alkhulayfi, B. A. (2016). Halal tourism: Emerging opportunities. Tourism Management Perspectives, 19, 137-143.

Neal, J. D., \& Gursoy, D. (2008). A multifaceted analysis of tourism satisfaction. Journal of Travel Research, 47(1), 53-62.

Nassar, M. A., Mostafa, M. M., \& Reisinger, Y. (2015). Factors influencing travel to Islamic destinations: An empirical analysis of Kuwaiti nationals. International Journal of Culture, Tourism and Hospitality Research, 9(1), 36-53.

Nuryanti, W. (1996). Heritage and postmodern tourism. Annals of Tourism Research, 23(2), 249260.

Ocampo, R. (2014). Philippines expands offerings to Muslim travelers. TTG Asia. Retrieved from https://www.ttgasia.com/2014/07/31/philippines-expands-offerings-to-muslimtravellers/

OECD. (2009). The impact of culture on tourism. Retrieved from https://www.oecd.org/cfe/tourism/theimpactofcultureontourism.htm

Oliver, R. (1993). Cognitive, affective and attribute bases of the satisfaction response. Journal of Consumer Research, 20(3), 418-430.

Oppermann, M.(2000).Tourism destination loyalty. Journal of Travel Research, 39(1), 78-84.

Ramayah, T., Yeap, J. A. L. \& Igatius, J. (2013). An empirical inquiry on knowledge sharing among academicians in higher learning institutions. Minerva, 51(2), 131-154.

Ringle, C. M., Wende, S., \& Becker, J. M. (2015). SmartPLS 3. Retrieved from http://www.smartpls.com.

Sboros, M. (2014) Moscow hotel goes halal in bid to attract global Muslim visitors. Biz News. Retrieved from https://www.biznews.com/travel/2014/10/27/moscow-hotel-goes-halalbid-attract-muslim-visitors-around-world/

Shafaei, F., \& Mohamed, B. (2015). Involvement and brand equity: A conceptual model for Muslim tourists. International Journal of Culture, Tourism and Hospitality Research, 9(1), 54-67.

Shakiry, A. S. (2006). The academy of Islamic tourism project. Retrieved from www.islamictourism.com

Shakona, M., Backman, K., Backman, S., Norman, W., Luo, Y., \& Duffy, L. (2015). Understanding the traveling behavior of Muslims in the United States. International Journal of Culture, Tourism and Hospitality Research, 9(1), 22-35.

Shakona, M. Y. (2013). The influence of religiosity on the intention of United States Muslim tourists to choose a shariah compliant hotel. ProQuest Dissertations and Theses, (December).

Sirikaya-Turk, E., Ekinci, Y., \& Martine, D. (2015). The efficacy of shopping value in predicting destination loyalty. Journal of Business Research, 68(9), 1878-1885.

Stepchenkova, S., \& Mills, J. E. (2010). Destination image: A meta-analysis of 2000-2007 research.Journal of Hospitality Marketing and Management, 19(6), 575-609.

Stone, M. (1974). Cross-validatory choice and assessment of statistical predictions. Journal of the Royal Statistical Society, 36(2), 111-147.

$\mathrm{Su}, \mathrm{H}$. J., Cheng, K. F. \& Huang, H. H. (2011) Empirical study of destination loyalty and its antecedent: The perspective of place attachment. The Service Industries Journal, 31(16), 2721-2739.

Sukanthasirikul, K., \& Trongpanich, W. (2016). Cultural tourism experience on customer satisfaction: Evidence from Thailand. Journal of Economic and Social Development, 3(1), $17-25$. 
Sun, X., Chi, C. G. Q., \& Xu, H. (2013). Developing destination loyalty: The case of Hainan Island. Annals of Tourism Research, 547-577.

Tanada, H. (2017). Ever growing Muslims community in the world and Japan.Waseda Weekly. Retrieved from www.waseda.jp.

Tasci, A.D.A. (2017). A quest for destination loyalty by profiling loyal traveller. Journal of Destination Marketing and Management, 6(3), 207-220.

Tieman, M. (2013). Consumer perception on halal meat logistics. British Food Journal, 115(8), $1112-1129$.

Timothy, D. J., \& Boyd, S. W. (2003). Heritage Tourism, London: Prentice Hall.

UNWTO. (2005). Tourism highlights, 2005 edition, Madrid: World Tourism Organization.

Wu, C. W. (2016). Destination loyalty modelling of the global tourism. Journal of Business Research, 69(6), 2213-2219.

Zailani, S., Kanapathy, K., Iranmesh, M., \& Tieman, M. (2015). Drivers of halal orientation strategy among halal food firms. British Food Journal, 117(8), 148 - 163.

Zamani-Farahani, H., \& Henderson, J. C. (2010). Islamic tourism and managing tourism development in Islamic societies: The cases of Iran and Saudi Arabia. International Journal of Tourism Research, 12(1), 79-89.

Zhou, L. (2005). Destination attributes that attract international tourists to Cape Town (Doctoral dissertation, University of the Western Cape). 